\title{
Linguistic Harassment Against Arab LGBTs on Cyberspace
}

\author{
Khalid Hudhayri ${ }^{1}$ \\ ${ }^{1}$ University of Umm Al-Qura, Makkah, Saudi Arabia \\ Correspondence: Khalid Hudhayri, University of Umm Al-Qura, 715 Al-Abdiya, 21955, Makkah, Saudi Arabia. \\ E-mail: Kohudhayri@uqu.edu.sa
}

Received: June 2, $2021 \quad$ Accepted: July 4, $2021 \quad$ Online Published: July 8, 2021

doi:10.5539/ijel.v11n4p58 URL: https://doi.org/10.5539/ijel.v11n4p58

\begin{abstract}
Opponents of lesbian, gay, bisexual, and transgenders (LGBTs) have always been creative in expressing harassment, in which they emphasize their resentment of LGBTs' "illegal" rights. In this modern era of technology, harassment is transmitted over digital applications. In light of new paradigms of defining cyberbullying, this research aims to describe the significant body of violent language, through which Arab LGBTs are attacked over Twitter. This is specifically important in building a corpus source for computational linguists working on a premature tracing of excluding language. Responses to 100 tweets posted by individuals affiliated with LGBT were analyzed to describe the precise act of discrimination. Results showed that Arab LGBTs experience prejudice against their sexual traits, mentality, poly-religious views, racial roots, and appearance via both verbal and visual means.
\end{abstract}

Keywords: LGBT, harassment, discrimination, verbal abuse, semiotics

\section{Introduction}

The endeavors of marginal and minor groups to be released from the power of major ones have been a vital cause of bullying against them (Zych, Farrington, Llorent, \& Ttofi, 2017). One group that has always been most vulnerable to intimidation and bullying is the lesbian, gay, bisexual, and transgenders (LGBTs). LGBTs is an umbrella term used to cover all instances of attraction and sexual desire for the same gender or both (Hall \& Rodgers, 2019). This unusual impetuousness is believed to be the pretext behind LGBTs' derogation. It has been hypothesized by Huett, Tumlison and Song (2017) that the LGBTs' ideology which transgresses the cultural identity of the majority, is widely stigmatized leading to much social conflict. Despite the critical emergency of passing legislations that warrant LGBTs' security, the crime rate against them has gradually increased causing a radical challenge to social unity (Stotzer, 2012, p. 2). Consequently, it was not surprising to declare the sustainability of social exclusion and undermine their experience (Fish, 2007). This queerness and underappreciation have led LGBTs to create their own community with whom they share rituals, beliefs (Sujana, setyawati, \& Ujanit, 2018), and even language of restricted discursive topics, exotic words, and frequent opaque slangs (Coates, 1996). Nevertheless, building their narrow network was not enough to prevent LGBTs from being traced and offended by the public.

With the ubiquity of the Internet, the trajectory has shifted from face-to-face bullying to digital cyberbullying (Barlett \& Coyne, 2014). According to Brydolf (2007), cyberbullying consists of acts of violence over media platforms against users (individuals) with whom we contradict across a multitude of attributes. The advancement of the Internet has been an open space to victimize LGBTs, with myriad instances of devaluation gradually increasing and disregarding social, psychological, and legal consequences (Wiederhold, 2014). This has proliferated efforts to protect discriminatory cyber-behaviors and to minimize hate (Dadvar \& de Jong, 2012). Nevertheless, Internet attacks against LGBTs remain a serious issue (Blackwell et al., 2016).

\subsection{LGBTs in the Arab World}

It is often claimed that LGBT devaluation is the product of growing up with a strict religious identity stemming from religious speech perpetuated by Muslim scholars (Qibtiyah, 2015). This is proved by cross-cultural studies that have found that children acquire discriminatory attitudes and disfavor LGBT from an early age even before school years (Farr, Salomon, Brown-lannuzzi, \& Brown, 2019, p. 140). Moreover, it has been documented that the religious aspect significantly affects classroom immersion activities among primary school LGBTs and extremely religious orthodox individuals (Tracey, 2018, p. 26). Thus, religious identity is thought to feed the 
social perception of LGBTs. In the Arab world, the dominance of Islam has conceptualized the cultural norms of the population (Pratt, 2007), where acts of LGBTs are strictly illicit and incur harsh penalties, and punishments derived from the adjudication of their religious book. This might be exemplified in the form of death sentences, flogging, or life imprisonment (Needham, 2013, p. 299). Such repression makes LGBTs socially amputated, pejorative, stigmatized, and invisible in the Arab world (Kreps, 2012, p. 1).

Several attempts have been taken by advocates and activists to shape society and promote the rights of LGBTs with respect to inter-bisexual relationships. First, by virtue of media platform privacy and policy, they started to interject themselves in societal discussions where they can express their ideas, participate in digital competitions, and comment on news, to name a few, while amid social stigma. It can be said that LGBTs have utilized social media platforms to extract themselves from privacy to publicity (Rodriguez, 2008). Second, they aimed to explain the argument that LGBTs were prevalent in the medieval era. Boronha (2014) documented ancient works of Arabic literature, in which words and poetic features reflect a sense of homosexual desire. Some went further to promote the assertion that all human beings are genetically ready for sexual attraction to the same gender or both (Bailey \& Zucker, 1995).

Third, and most importantly, LGBTs have begun to combat the religious discourse of Muslims'. Elsaadawi (1992) widely criticized the language of the Qur'an, as it prevents personal freedom. She claimed that LGBTs' preferences are expunged. She further stated that personal freedom of sexual orientation is superior to social intervention, renewing her calls for humanity to disobey the Quran's unfair judgments (Tag El-Din, 2009). This emboldens LGBTs to raise the anti-Quranic perspective (Neo, 2003) assault the omnipotence and soul of God, and question the realities of paradise and hell. Perhaps this religious context is what triggers the offending language through which LGBTs are attacked over social media.

\subsection{Harassing Cyberspace Language}

The definitions of harassing, discriminatory, and aggressive language are somehow overlapping, making it difficult to differentiate them. Thus, some linguists group them under one category of hurtful language that varies slightly in purpose (ElSherief, Kulkarni, Nguyen, Wang, \& Belding-Royer, 2018). The most common linguistic discrimination over cyberspace is direct verbal abuse. According to Ayuwat (2017), verbal abuse is any act of violence transmitted through the language, whether oral or written. Further, any non-contextual adjustment of voice such as, a louder tone, and a rising intonation, is also considered an act of verbal harassment.

A detailed description of an updated paradigm of verbal harassment was provided by Rezvan et al. (2018, pp. 2-3). According to them, verbal harassment (abuse) is classified into five major discriminatory contexts: (1) sexual harassment, which is the act of discriminating against one's sexual orientation using vulgar language; (2) racial harassment, which is considered to be violence against ethnic groups, nationhood, cultural upbringings, and the surrounding environment; (3) appearance harassment, which is the kind of language that derogates a person for their color or facial features; (4) intellectual harassment, which is discrimination against beliefs, ideas, and conceptualizations, usually with words indicating abnormality and dumbness; and (5) political harassment, which is language against a political stance, movement, or religious sect.

Recently, another method of cyber-discrimination has emerged with much investigation. Semiotic harassment has attracted the attention of many studies, especially those on racial and political exclusion. Semiotics is the study of the hidden connotational meaning shared by language users; it is the reinterpretation of a visual sign to fit a context (Chandler, 2005). This reinterpretation is the result of linking two levels of representation. According to Sassure (1974), semiotics is the course of coalescing a visual sign to a predetermined, socially constructed conceptualization. What we mean by "socially constructed" is that the meaning derived from symbols and visualities is not linguistically fixed; rather, it is socially taught based on conventional use and the way this relation is developed by the agreement of language users (Cohen \& Tieyze, 2007, p. 6). Accordingly, semiotics is the process of placing signs into a larger cultural background.

It has been stated that semiotic harassment is the indirect victimization via a visualized mean that can be translated conventionally into a linguistic message, including iconized pictures, emojis, or any contextualized means (Nailufar, 2014). This indirectness has a vivid value in acts of cyberbullying. Bullying others indirectly is a kind of manipulation of one's real intention. It causes harm, seeks power, and engages in cyberbullying while hiding social identity (Duffy, 2004, p. 3). Therefore, compared with direct cyberbullying, indirect cyberbullying is less noticeable.

\section{Literature Review}

Although LGBT discrimination has recently been interjected into linguistics, the majority of LGBT studies are 
the product of different social domains, and studies focusing on the LGBT audience's cyber behavior are rather rare. GLSEN, CiPHR and CCRC (2013) undertook an extensive survey aimed to unravel LGBTs' cyberspace harassment into demographic, ethnic, and purposeful variables. The report indicated that white LGBTs experience more cyberbullying compared with other individuals of varied racial backgrounds. Moreover, among many other factors, it was documented that most attacks take place because the public declares their sexual intent Part of this conclusion has already been proved by Cochran and Mays (2000), who analyzed a questionnaire of 2917 homo and heterosexual participants in relation to mental disorders. It was found that the harm of cyber-sexual discrimination has raised the level of suicidal intention among LGBTs. Studies that have surveyed the correlation of LGBTs' disposition to ending life found that cyberbullying has radically raised their suicidal ratings.

Jerome (2019) recruited 132 LGBTs to participate in controlled questionnaire and structured interviews. He aimed to collectively measure the variants of cybercrime experienced by LGBTs. He found that most subjects had a previous experience of attacks, including hacking, personification, and verbal humiliation. However, this study disclosed the general pattern of cybercrime, rather than provided a detailed analysis. Thus, further elaboration of the findings, especially those pertinent to verbal insult was needed. Lu, Chang, Lin and Yen (2018) sought to determine the emotional perception of LGBTs toward cyberspace. Three hundred two LGBTs were asked to fill out a semi authentic questionnaire testing the overall positivity and/or negativity of their experience. One third of them expressed their dissatisfaction with cyberspace because of excessive verbal abuse and racial discrimination.

Mkhize, Nunlall and Gopal (2020, pp. 4-6) examined the social behavior of LGBT perpetrators. After a careful tracing of data between 2017 and 2019, they listed different annoying strategies. They found newly created accounts, with no history and/or profile, used to invade the privacy of homosexual groups and bully them. These homosexuals were attacked via an approach of telling stories of fake experiences and incidents of social ignorance. Takizawa, Maughan and Areseneault (2014) commented that such kind of psychological attacking might lead to higher levels of anxiety, causing a lack of self-esteem, and severe psychological abnormality. Further, Ali and Mothar (2020) qualitatively analyzed the discourse of LGBT proponents posted over twitter to support LGBT rights. The study shed light on tweets that highlight social issues of such a minority group. According to the results, avoiding cyberspace linguistic abuse was extremely called for.

Al-Abbas and Haider's (2020) longitudinal study was one of the few that analyzed the discourse of LGBTs addressing terms in the reports of official media channels over nine years. It has been argued that the media (social, public, digital) embodies LGBTs indirectly with semantic vagueness, depicting their insecure status and odd social character. They argued that official platforms are widely affected by the expanded cultural view of LGBTs. Therefore, they perpetuate the extremeness against LGBTs, disregarding the objective goal of media as a tool for peace and unity. Moreover, in a reproduced project conducted by Out Right Action International (2016), it has been found that Arab Twitter and other means of media discourse are dominated by threatening language that encourages detention, arrests, and legal surveillance of LGBTs. The project provided examples of discursive bias against LGBTs across different Arab countries. Furthermore, a database of the most vulgar words used to harass LGBTs was identified. However, the project neither illustrated the token of frequency of these expressions, nor placed the research into a larger harassment frame.

To examine the strategies employed by LGBTs in response to cyberattacks, Hynuh (2015) conducted a study to evaluate how LGBTs perceive the degradation of cyberspace. A total of 39 LGBTs were invited to match diversified victimization scenes with a prelisted reaction indicator. The findings showed that most LGBTs deal with such acts of violence tolerantly without denial or escalation. It has been found that most cyberbullying scenarios occur with attempts at self-distraction. This perhaps pretexts the wider circulation of the fact that LGBTs are ranked lower in reporting cyberbullying crimes to authorities (Williams \& Robinson, 2004).

\section{Method}

\subsection{Significance of the Study}

Most of the literature has focused on general issues in relation to LGBTs such as the rate of harassment they experience, theoretically measuring their feelings regarding harassment, and reminding the public of their rights, to name is few. However, to the best of my knowledge, no paper has explored the discriminatory reactions against LGBTs in light of the major types of linguistic abuse described by Rezvan et al. (2018) or the newly birthed discrimination of signs (semiotic harassment) succinctly defined by Nailufar (2014). Moreover, frequency tokens of the types of these subdivided harassment paradigms have been completely rejected, especially in the cyberbullying behavior of Arab perpetrators. This research aims to examine these issues 
quantitatively and qualitatively, investigating the verbal/semiotic harassment experienced by LGBTs, as well as identifying the frequency token of both.

Additionally, this paper contributes to the field of natural language processing and programming, which targets the analysis of LGBT discriminatory language for early detection and purging before public presentation (Tomkins, Getoor, Chen, \& Zhang, 2018). It has been argued that a major obstacle for developing such a program is the paucity of register variation detection, which is not easily caught. Accordingly, this study hopes to build a small database of harassment expressions recorded against LGBTs using varied linguistic choices. Data will be analysed in reference to lexical meaning rather than word tokens.

The research questions can be summarized as follows:

1) What type of cyber-harassing do Arab LGBTs suffer from, verbal, semiotic, or both?

2) What specific types of these two harassment languages are Arab LGBTS attacked with?

3) How do these specific ones vary in frequency? What is the most and least frequent?

\subsection{Data Collection and Processing}

The qualitative data are based on 100 randomly extracted tweets of Arab individuals whose post, profiles, and affiliations are with LGBTs. The pretext behind choosing Twitter is its suitability for gathering a reliable set of data. Twitter is a safe place for LGBTs to hide their personality, avoiding social stigma while freely browsing ideas and beliefs. All responses carrying violent language will be tracked for careful analysis against major and minor verbal/semiotic discrimination. For the sake of simplification, tweets will be collected from accounts with a high rate of followers and with a clear declaration of being LGBT. Any identity clue, profile picture, and personal information will be manually erased, leaving out the content only. Quantitatively, the figures will be examined with the assistance of JASP by focusing on descriptive aspects.

\section{Results and Discussion}

Influential accounts of consistent watching and posting were rare, yet, it was found that LGBTs in the Arab world are creating their own national Twitter group, for instance, the Egyptian LGBTs, the Saudi LGBTs, to name a few. This has maximized the opportunity of gathering similar and redundant derogatory expressions with dialectal differences. As shown in the literature, LGBTs' sexual admission places them on the focus of attackers. Not only anonymous, but also verified accounts were found to victimize LGBTs. According to Table 1, verbal (linguistic) abuse is more prevalent as a medium of passing insults against Arab LGBTs over cyberspace. A total of 876 derogatory expressions were recorded (a complete list is given in Appendix A). However, semiotic harassment was radically less frequently used over media platforms. Thirty-two insults were covered and divided unevenly between different visual languages.

This section will further explain the findings, focusing on unique and fundamental patterns of cyberbullying observed over the analysis. The longest part, verbal abuse, will be divided into internal sections, while semiotic harassment will be wholly discussed in a single unified subsection.

Table 1. Descriptive statistics of major mean of LGBTs cyberbullying

\begin{tabular}{lllllll}
\hline & Mean & Range & SD & Sum. & Max & Min. \\
\hline Verbal abuse & 175.2 & 410 & 186.45562 & 876 & 431 & 21 \\
Semiotic & 10.66 & 18 & 9.29157 & 32 & 21 & 3 \\
\hline
\end{tabular}

\subsection{Verbal (Linguistic) Abuse}

The obtained data further highlights conservative social identity as an impediment to the trajectory of establishing equality for LGBTs in the Arab world (Helie, 2012). The data indicate that LGBTs are subjected to various forms of verbal (linguistic) attacks across all domains: sexual, political, intellectual, racial, and aesthetics. As shown in Table 2, LGBTs are mostly oppressed using words of sexual abuse, while intellectual abuse is ranked second, with adjectives indicating the denial of LGBTs' mental ideations. Political and racial bullying are limited, while appearance-related bullying constitutes the lower end of the hierarchy. Instances of these verbal abuse categorizations are varied because of the radical frequency of word appearance, where some are more repetitive while others have appeared once only; these will be further categorized under "others" in the next sections. 
Table 2. Descriptive statistics of sub-types of verbal (linguistic) cyberbullying

\begin{tabular}{lllllll}
\hline & Mean & Range & SD & Sum. & Max & Min. \\
\hline Sexual & 10.51 & 115 & 26.57266 & 431 & 116 & 1 \\
Political & 3 & 10 & 2.57074 & 72 & 21 & 1 \\
Intellectual & $2.88^{*}$ & $25^{*}$ & $6.78718^{*}$ & 316 & 26 & 1 \\
Racial & 2.25 & 9 & 2.23607 & 36 & 10 & 1 \\
Appearance & 1.615 & 2 & 0.85163 & 21 & 3 & 1 \\
\hline
\end{tabular}

Note. ${ }^{*}$ Not exact.

\subsubsection{Verbal Sexual Abuse}

The U.S Equal Employment Opportunity Commission [EEOC] (n.d.) defines sexual abuse as acts of frequent verbal humiliation against others with negative comments and sexual gestures. The findings attest to the higher rate of sexual violence that LGBTs experience. Arab LGBTs are no exception; the records found abundant sexually transgressing expressions indicating disfavor of LGBTs and their thoughts. Mukhanath (sissy) and shath (queer) were prevalent across the data; they equally ranked first with 116 occurrences. Also, the belittling of LGBTs' tendency toward bisexualism was addressed by the word Methli (bisexual) with 48 tokens.

Similarly, some other expressions with religious roots were found to be popular. Homosexuality began in 1900 B.C. with the story of the folk of Lout, who were punished for their sodomy (Fadillah, 2016, p. 1). Since then, the adjective Loti has been coined to describe a person who is engaged in sodomy. This same expression is extremely common in the Arab world to describe LGBTs, appearing 53 times. Insulting LGBTs for their homosexuality came with the expression of the same meaning but varied according to the geographical area and style of speaking. These included, the Omani Makhjoof, the Hijazi Mibsbs, and the Egyptian Kurani, which are all equivalent "homosexual".

It is often argued that the feminist and queer movements have emerged to struggle against social marginalization and the practice of male supremacy (Gedro \& Mizzi, 2014, p. 446). Therefore, there was a tendency to associate LGBTs with the slummed status of women in the Arab world (Khodary, Salah, \& Mohsen, 2000). Female-attributed expressions, such as Bint (girl), Anisa (lady), and Okhti (sister) were found to express disrespect. In the same vein, the word Markoob (ridden or taken by) was pejoratively used to simulate the position of women relative to men during intercourse. Furthermore, words such as gay, shemale, and pussy have been literally borrowed to sexually harass Arab LGBTs.

Table 3. Statistical frequency of verbal sexual abuse words.

\begin{tabular}{lll}
\hline & Frequency of Occurrence & Frequency Rate \\
\hline Mukhanath & 116 & 0.26 \\
Shath & 116 & 0.26 \\
Methli & 48 & 0.11 \\
Louti & 53 & 0.12 \\
Others & 98 & 0.22 \\
\hline
\end{tabular}

\subsubsection{Verbal Political Abuse}

The inseparability of religion and politics is inevitable. It is always thought that religion and politics are an interwoven social construct used to claim power. Thus far, social dominance is achieved by passing political agenda through a subservient religious heritage (Beyers, 2015). Therefore, determining the political humiliation of LGBTs in religious contexts was logical. Specifically, such political harassment was confined to critical religious arguments. It was found that all expressions were used to politically cyberbully LGBTs, which emerge from a criticism of a divine command that prohibits LGBT acts, and distorts holy verses. Consistent with Table 4, the word Mulhid (atheist) was most commonly utilized as a condemnation of anti-Islamic views by LGBTs. This rejection of precious adjudication is perhaps what led conservatives to call them the equivalent of being an atheist, which theologically symbolizes one's disbelief in God and jurisprudence (Cragun, 2016, p. 303). Apparently, the ideology of LGBTs upholds the liberal philosophy of freedom of religion and actions (Worthen, 2020). Accordingly, the negative connotational meaning of Libraly (liberal) is used to attack LGBTs for their open-minded sexual intents. In parallel, words such as I'lmani (secularist) and Mutatarif (extremist) redundantly appeared to reject the freedom of social attraction called for by LGBTs. 
An interesting cyberbullying expression with a religious aspect describing the conflict between Islamic sects is the word, Shea. According to Perazzo (n.d., p. 2), Shea constitutes the minor Islamic camp under persecution of the majority Sunnah for conflicts regarding religious beliefs and rituals. Therefore, the word Shea, with six occurrences, was used to indicate the queerness of LGBTs and to be partly undefinable by the majority. Thus, the confrontation of Sunnah and Shea and their act of rejection was rhetorically personified to express the same reality between Arab conservatives and their LGBT counterparts.

With the prominence of religious studies as an independent field of inquiry, the term Islamophobia was interjected into theories of theology. It has been defined as prejudice against Islam, and the process of associating fake interpretations to its adjudications (Bleich, 2011). The adjectival term was coined literally by Arab cyberspace perpetrators to harass LGBTs; it implies the attribution of LGBTs' attempt to deform and spread a negative stereotypical image of Islam.

A fancy expression with a deep discursive message was derived from the music industry. Nowadays, technology has brought folks into proximity and cultural contact. This integration of cultures sometimes has its disadvantages and critical consequences; this is due to its impact on beliefs, lifestyles, and cognitive perception (Zamil, 2013, p. 1). Recently, K-'pop culture has invaded the Arab media with a constant increase in popularity among the youth (Park, Kim, Ko, \& Chaffar, 2017). According to Diana (2016, p. 23), K-'pop culture is the kind of music that reflects the attitudes, credos, and perception of a nontraditional, societally exclusive rituals of a foreign (Korean) community. Based on this, the data recorded the most contextually inferred form of distinction against LGBTs with the expression Kibob (a transliteration of K-'pop, being a K-'pop advocate.) Ethno-semantically, this could be interpreted as a criticism symbolizing the attempts of LGBTs to import views with no conventional roots, views that, despite no necessarily being upheld by K-'pop musicians, are socially obtrusive, clearly indicating LGBTs' promotion of homosexuality.

Table 4. Statistical frequency of verbal political abuse

\begin{tabular}{lll}
\hline & Frequency of Occurrence & Frequency Rate \\
\hline Librali & 7 & 0.09 \\
Mulhid & 11 & 0.15 \\
I'lmani & 6 & 0.08 \\
Mutatarif & 6 & 0.08 \\
Shea & 6 & 0.08 \\
& & \\
Others & 36 & 0.5 \\
\hline
\end{tabular}

\subsubsection{Verbal Intellectual Abuse}

Intellectual harassment is defined as verbal acts of ridiculing the thoughts of others, diminuting their perspectives, and emptying their opinions (Iroegbu, 2019). A plethora of intellectual (mental) derogation was recorded in our data. Psychologists have revealed that feelings of disgust toward same-gender sexual attraction are somehow normal. Kiss, Melanie and Morrison (2018, pp. 5-6) argued that homosexual disgust is triggered by the violation of individualistic predetermined behavioral traits. This finding is further consolidated by our analysis. It was found that expressing dissonance was common across the public with the literal word Mukref (disgusting). Similarly, another word expressing the same emotion was found highly frequent: Qather (dirty) appeared 26 times.

The nurture/nature debate of the originality of homosexuality has become an area of long-standing disagreement among scholars. Whether same-sex sexual attraction is the outcome of genetic predisposition, or the result of environmental upbringing remains unsolved (Whitehead, 2011, p. 83). However, it seemed that most of the population are affected by the environmental drive of homosexuality. This was reflected by the bullying against LGBTs using the word Thed altab'ea (anti-naturalism). This perhaps simulates the populations' wider credence of the inimicality of LGBTs to instinctiveness.

The religious features associated with Shea was again addressed, but in a behavioral (intellectual) manner. The word Rafidi (denotes a person who competes the majority) is a cultural term used to refer to shea. The origin of this term is the fact that they are entirely in conflict with mainstream thoughts. Thus, Rafidi was used to imply the weirdness of LGBTs' abnormal conduct. Another notable example of practicing the cultural connotational meaning was the prevalence of the word Himar (donkey). According to Anjomshoa and Sadighi (2015, p. 65), the Eastern cultural image of a donkey is associated with dumbness, triviality, and non-seriousness. Himar has 
been used as an insult roughly six times, indicating the absurdity, and worthlessness of ideas posted by LGBTs. Table 5 shows some statistical figures for harassment words discriminating against the intellectual properties of LGBTs over cyberspace.

Table 5. Statistical frequency of verbal intellectual abuse.

\begin{tabular}{lll}
\hline & Frequency of Occurrence & Frequency Rate \\
\hline Mukrif & 22 & 0.06 \\
Kather & 26 & 0.08 \\
Thed altabe' $a$ & 26 & 0.08 \\
Others & 242 & 0.76 \\
\hline
\end{tabular}

\subsubsection{Verbal Racial Abuse}

Unlike face-to-face racial discrimination, it is usually assumed that online racial gestures are inventive. Keum and Miller (2018) stated that Internet racism can be expressed via visual material (photos or videos) or verbal expressions. In this research, only instances of verbal racial abuse could be collected with less prevalence, compared to sexual, political, and intellectual abuse. It was observed that racial discrimination is linked to political stance in the sense that most of them were the product of political instability in the Arab world, and again have something to do with Shea. The Middle Eastern rivalry with Iran, a majority Shea nation, and its believed instigating role have affected every aspect of bipolar interactions: economic, political, and social (Cerioli, 2018). Cyberspace is not an exception, and apart from the battle. An interesting discriminatory expression posted as a response to a Saudi LGBT member was Irani. Preponderantly, this was used metaphorically to express racial exclusion and non-belonging to the community. Similarly, the word Asfahani (from Asfahan, a city in Iran) was also found once. Obviously, it had the same implication of socially separating and refuting LGBTs.

Saudi Arabia is known for its sectarian variation, with a Sunnah majority and a Shea minotiry. Al-Qtif (name of a city) is believed to be the hometown of nearly all Shea (Perazzo, n.d.). Further, the conflict between these two sects is increasing across all disciplines in terms of their radical religious customs. In connection, a third notable example of racial discrimination was given as a response to a Saudi LGBT member. The word Qatifi (from Al-Qatif) was used to object to a call for sexual freedom. It seems clear that exclusion and expulsion are hidden within such an expression. Similarly, attaching the concept of being Shea to discriminate LGBTs was also evident in the expression Eraqi (from Iraq). Again, this enunciates the LGBT/conservative clash by reference to the unstable situation involving Sunna and Shea in Iraq (Marbaniang, 2014).

Racial abuse also manifested through other forms, including Ajnabi (foreigner) and Mujanas (non-indigenous). However, the most frequent sense of deportation was the call directed to LGBTs, Yihajer/Hajer (migrate-as command) from lands with a conservative culture, indicating the impossibility of absorbing LGBTs as decent individuals in society. Table 6 provides an overview of verbal racial cyberbullying against LGBTs.

Table 6. Statistical frequency of verbal political abuse

\begin{tabular}{lll}
\hline & Frequency of Occurrence & Frequency Rate \\
\hline Hjaer & 10 & 0.27 \\
Irani & 1 & 0.02 \\
Asfahani & 1 & 0.02 \\
Qatifi & 1 & 0.02 \\
Mujanas & 3 & 0.08 \\
Others & 20 & 0.55 \\
\hline
\end{tabular}

\subsubsection{Verbal Appearance-Related Abuse}

Previous studies concerning patterns of cyberbullying have acknowledged appearance-related features as the most cited reason for discrimination (Berne, Frisen, \& Kling, 2014, p. 527). Conversely, in Table 1, and further elaborated in Table 7, the results show only 21 instances of degradation against appearance; this could be linked to the disparity of the population. According to Cassidy, Faucher and Jackson (2009), comments on body size were among the most common attributes to cyberbully victims. They added that discriminating against weight constitutes one-third of the data. In parallel with that, it was observed that LGBTs are sometimes described as 
Wazn banouti (girly body). This is used to express the social inferiority of both women and LGBTs. Again, to associate the defamatory status of LGBTs and women, other derogatory replies were detected. Expressions such as Sout banouti (girly voice) and Libs banouti (girly dress) most frequent.

Table 7. Statistical frequency of verbal appearance Abuse

\begin{tabular}{lll}
\hline & Frequency of Occurrence & Frequency Rate \\
\hline Sout banouti & 3 & 0.14 \\
Wazn banouti & 1 & 0.04 \\
Libs banouti & 3 & 0.14 \\
Others & 14 & 0.66 \\
\hline
\end{tabular}

\subsection{Semiotic Abuse}

The adoption of semiotics added new insights into communication and its tools. It helps disclose the hidden sentimental value of an experience in a culturally codified way (Lanigan, 1988). These values are created from the interpersonal social belief of an object, entity, or doctrine (Jha, Raj, \& Gangwar, 2017), which are completely meaningful but are in a non-verbal medium (Marriott \& Meyer, 1998). Traditionally, visual signs are miscellaneous, covering whatever graphically designed product that is utilized influentially to aid meaning and express intention (Dewan, 2015). According to Smith and Martinez (1995), new trends of harassment can be embodied visually rather than verbally. They added that content analysis of signs is paramount in foreseeing the intention and depiction of harassment. Such type of harassment was found in our data although, as illustrated in Table 1, visual harassment was incidental, yet, the results extracted three major paradigms of semiotic cyberbullying against targeted LGBTs: images, videos, and emojis.

Table 8. Statistical frequency of semiotic abuse

\begin{tabular}{lll}
\hline & Frequency of Occurrence & Frequency Rate \\
\hline Images & 21 & 0.56 \\
Videos & 8 & 0.25 \\
Emojis & 3 & 0.09 \\
\hline
\end{tabular}

The cultural oppression of LGBTs has identified an ironic mentality of treatment among the Arab community. This irony is reflected by the embarrassing characterization of LGBTs in formal/informal writings (Guardi, 2014). However, the technicality of this term and the hard distinction between an ironic image by nature and an ironic context has further led to miscomprehension (Currie, 2012). This paper advocates the definition of irony given by Grice (1975). According to him, irony is the act of tacitly disapproving and opposing others' ideas by comments that cannot be understood, but within a context. Perhaps, the best fitting reflections of irony are images or pictures (Currie, 2012). Consequently, it was not surprising to document the act of mugging LGBTs via ironic pictures in almost $56 \%$ of visually harassing gestures.

Almost all images carried a sense of culturally explained humiliation. Some eloquently delineated the rainbow flag of LGBTs being swept away to a sanitary hole (Figure 1). This metaphor illustrates the marking down of LGBTs, showing a rejection of their thoughts in society. Another interesting image presents a conversation between a puppy and a dog (a son and a father) while the LGBT flag is thrown in a fireplace. This implies the "garbage" ideas advocated by LGBTs (Figure 2). Another modality of more relaxed semiotic cyberbullying is video attacks. It shows a process of transmitting vulgar language to victims over a clip of a certain length (Soni $\&$ Singh, 2018, p. 2). In our data, discriminatory clips were shown eight times as a carrier of inferiority, mostly through ephemeral swearing that attacks the intellectuality of LGBTs. 


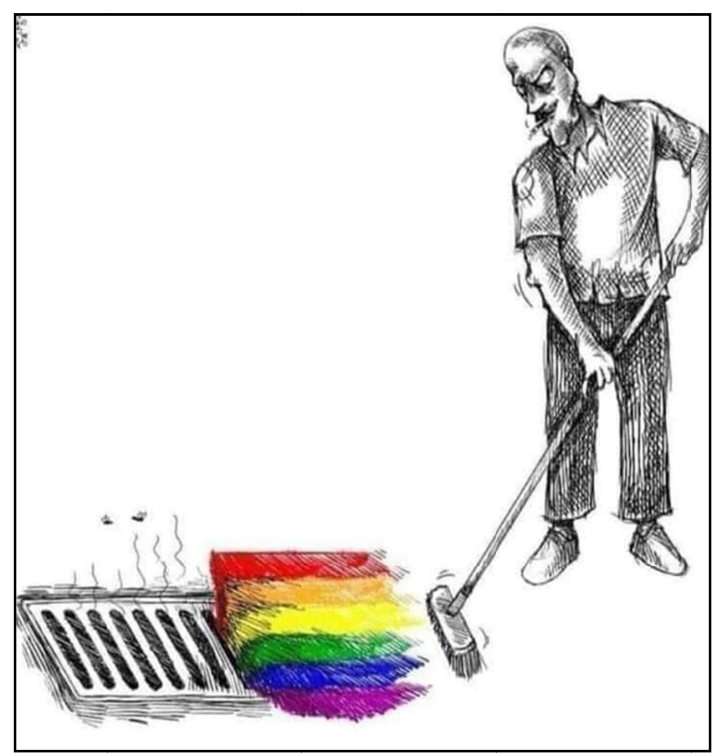

Figure 1. Symbolizing the social rejection of LGBTs

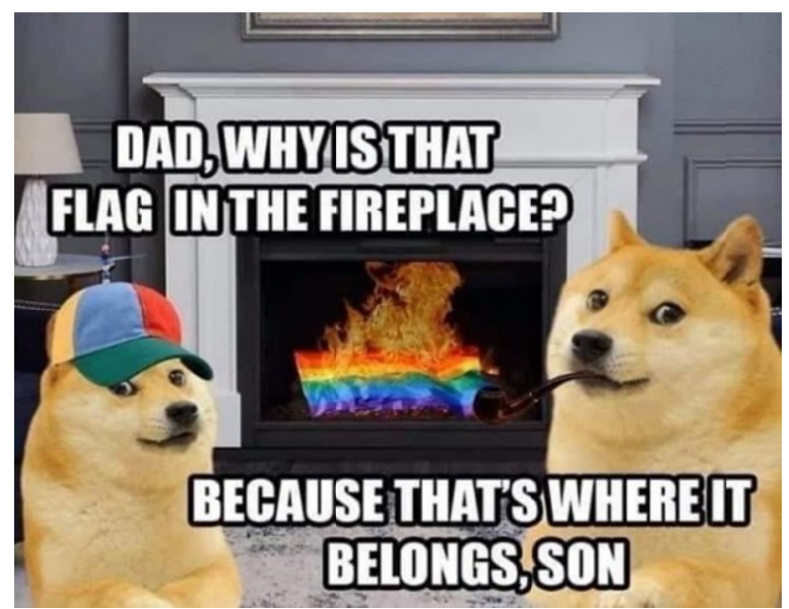

Figure 2. Symbolizing the "garbage" Sense of LGBTs

Recently, emojis have invaded all intercultural online communications. Even though, the exact meaning of emoji is vague, most cyberspace users have at least an idea of it. Simply put, emojis are a bundle of 722 computerized symbols used to mirror a multitude of perceptual properties (Al-Rashdi, 2015, p. 4). It has been stated that the inherently semantic wealth of emojis enable individuals to translate emotions wordlessly (Danesi, 2016). Consequently, one such emotional value is harassment. Our data lacks the plentifulness of emojis as a discriminatory tool; this could be due to the cultural variation in the substantial use of emojis. According to our analysis, three codified emojis were found to reflect an intellectual attack.

Section 4.1.4 mentioned that Mukrif (disgusting) is widely used expression to reject the ideas of LGBTs. This has also been expressed with a vomiting face (《). According to Emojipedia, this face is the apparent rhetorical signifier of disgust. Therefore, it would be rational enough to consider it a form of digitized intellectual harassment. However, some other emojis are sufficiently mysterious and far apart from ease of interpretation. This stems from the dynamism of perceiving emojis, and the course of associating them with a unified cultural meaning (Park, Barash, Fink, \& Cha, 2013). One such emojis that causes great confusion due to cultural disparities is the dog face $\left({ }^{*}\right)$. In the West, a dog is a dignified symbol of positive traits and good manners. The interpretation of a dog is consistently attached to dearness, holiness, and loyalty (Yinggang \& Xuena, 2015). Meanwhile, the same symbol implies dirtiness, unfaithfulness, and derogation in Eastern culture (Fatkurrohman, 2014). Therefore, it would be possible to call somebody a dog as compliment in the West, but clearly not in the East. In our data, consequently, this sign was once used to combine LGBTs' call for sexual freedom and the 
derogatory cultural meaning of dog in Arab societies, indicating expungement and exclusion, although this symbol can also be used to make fun of somebody's appearance in the Arab culture. Nevertheless, the contextual meaning of the tweet and the reply, clearly proved that it was an intellectual attack.

The most remarkable offensive emoji to criticize LGBTs was the frog face ( Specifically, frogs entail a significant connotative interpretation in Arabic cultural figurative language. According to Ben Salamh and Meelej (2018), a frog metaphorically iconizes the unsuitability and the abolishment of someone's behaviour. Therefore, the disguised meaning of the reply was built on the cultural awareness of the concept of a frog. It indicates the inappropriateness of LGBTs' acts, rights, and thoughts in a conservative Islamic community. This was also evident in some other verbal insults that personify LGBTs to the croaking of a frog, reflecting the same idea of the emoji.

\section{Conclusion}

The current study examined forms of harassment against queer Arabs over Twitter. The descriptive analysis of replies to 100 haphazard tweets revealed that LGBTs sustain radical verbal attacks targeting their perspectives regarding sex, political stance, ethnicity, intellectual thoughts, and appearance. Further, they were also victims of visually humiliating materials, including photos, videos, and emojis of cultural significance. The objective of this paper was to create a data source containing existential patterns of Arab LGBTs' harassment cyberspace. Nevertheless, it has several limitations: (1) The need to verify samples of tweets extracted from a limited set of accounts affected both the quantity and quality of analysis. (2) Some comments have been found to be clearly discriminatory. However, they were in the gray zone between intellectual or racial harassment, for example. This may propose more models of harassment types. (3) The analysis has overlooked discriminatory modes (verbal/visual) with extremely offensive gestures for nations, regimes, authorities, and more. This study has to be consolidated by others covering these weak points, as well as comparative papers on acts of violence against LGBTs in the West.

\section{References}

Al-Abbas, L., \& Haider, A. S. (2020). The representation of homosexual in Arabic-language news outlets. Equality, Diversity, and Inclusion, 40(3), 309-337. https://doi.org/10.1108/EDI-05-2020-0130

Al-Rashdi, F. (2015). Forms and functions of emojis in whatsapp interaction among Omanis. Ph.D thesis, Georgetown University.

Ali, M. N., \& Mothar, N. M. M. (2020). Discourses on Twitter contribute to the concept of resilience in the LGBT community in Malaysia. Esteem Journal of Social Sciences and Humanities, 5, $27-47$.

Anjomshowa, L., \& Sadighi, F. (2015). The comparison of connotative meaning in animal words between English and Persian expressions and their translation. International Journal on Studies in English Language and Literature (IJSELL), 3(2), 65-77.

Ayuwat, T. (2017). Verbal abuse among students un Ubon Ratchathani province, Thailand. International Journal of Criminal Justice Sciences (IJCJS), 12(1), 154-167.

Bailey, J. M., \& Zucker, K. J. (1995). Childhood sex-typed behavior and sexual orientation: A conceptual analysis and quantitative review. Developmental Psychology, 31, 43-55. https://doi.org/10.1037/0012-1649.31.1.43

Barlett, C., \& Coyne, S. M. (2014). A meta-analysis of sex differences in cyber-bullying behavior: The moderating role of age. Aggressive Behavior, 40, 474-488. https://doi.org/10.1002/ab.21555

Ben Salamh, S., \& Maalej, Z. A. (2018). A cultural linguistic perspective on animal proverbs, with special reference to two dialects of Arabic. AWEJ for Translation and Literary Studies, 2(4), 21-40. https://doi.org/10.24093/awejtls/vol2no4.2

Berne, S., Frisen, A., \& Kling, J. (2014). Appearance-related cyberbullying: A qualitative investigation of characteristics, content, reason, and effects. Body Image, 11, 527-533. https://doi.org/10.1016/j.bodyim.2014.08.006

Blackwell, L., Hardy, J., Ammari, T., Veinot, T., Lampe, C., \& Schoenebeck, S. (2016). LGBT Parents and social media: Advocacy, privacy, and disclosure during shifting social movements. Unknown Publisher. https://doi.org/10.1145/2858036.2858342

Bleich, E. (2011). What is Islamophobia and how much is there? Theorizing and measuring an emerging comparative concept. American Behavioral Scientist, 55(12). https://doi.org/10.1177/0002764211409387 
Boronha, M. A. D. F. (2014). Male homosexuality in Islamic normative and in the mujun literature of al-Andulus and the Maghreb between 10th and 13th centuries. MA Thesis, University of Lisbon.

Brydolf, C. (2007). Minding My-space: Balancing the benefits and risks of students' online social networks. Education Digest, 73(2), 4-8.

Cassidy, W., Faucher, C., \& Jackson, M. (2019). Cyberbullying at university in international contexts (1st ed.). Routledge. https://doi.org/10.4324/9781315189406-1

Cerioli, L. G. (2018). Roles and international behaviour: Saudi-Iranian rivalry in Bahrain's and Yemen's Arab spring. Contexto International, 40(2). https://doi.org/10.1590/s0102-8529.2018400200010

Chandler, B. (2005). Semiotics: The basics (2nd ed.). Routledge: Tylor and Francis Group.

Coates, J. (1996). Women talk. Oxford: Blackwell.

Cochran, S. D., \& Mays, V. M. (2000). Lifetime prevalence of suicidal symptoms and affective disorders among men reporting same-sex sexual partners: Results from the NHANES III. American Journal of Public Health, 90, 573-578. https://doi.org/10.2105/AJPH.90.4.573

Cohen, L., \& Tietze, L. (2007). Pedagogy and the linguistic turn: Developing understanding through semiotics. Management Learning, 38(1), 45-60. https://doi.org/10.1177/1350507607073022

Cragun, R. T. (2016). Nonreligion and Atheism. In D. Yamane (Ed.), Handbook of religion and society. Springer International Publishing. https://doi.org/10.1007/978-3-319-31395-5_16

Currie, G. (2012). The irony in pictures. Hallward Library, University of Nottingham.

Dadvar, M., \& de Jong, F. (2012). Cyberbullying detection: A step toward a safer internet yard. Human Media Interaction Group, University of Twente. https://doi.org/10.1145/2187980.2187995

Danesi, M. (2016). The semiotics of emoji: The rise of visual language in the age of the internet. London: Bloomsbury Publishing.

Dewan, P. (2015). Words versus pictures: Leveraging the research on visual communication. The Canadian Journal of Library and Information Practice and Research, 10(1). https://doi.org/10.21083/partnership.v10i1.3137

Diana, I. N. (2016). The influence of K-pop culture on students' lifestyle and political knowledge at social science education. S.Pd thesis, Science State Islamic University of Maulana Malik Ibrahim Malang.

Duffy, A. L. (2004). Bullying in schools: A social identity perspective. Ph.D. Thesis, Griffith University.

Elsaadawi, N. (1982). Woman and Islam. Women's Studies International Forum, 5(2), 193-206. https://doi.org/10.1016/0277-5395(82)90027-9

ElSherief, M., Kulkarani, V., Nguyen, D., Wang, W. Y., \& Belding Royer, E. M. (2018). Hate lingo: A target-based linguistic analysis of hate speech in social media. CoRR.

Fadillah, A. (2016). Homosexuality: A comparison between Islamic and Western perspective. Unknow Publisher. Retrieved from https://www.researchgate.net/publication/303790206_Homosexuality_a_Comparison_between_Islamic_and _Western_Perspective.

Farr, R. H., Salomon, I., Jazmin, L., Lannuzi, B., \& Brown, C. S. (2019). Elementary school-age children's attitudes toward children in same-sex parent families. Journal of LGBT Family Studies, 15(2), 127-150. https://doi.org/10.1080/1550428X.2018.1452659

Fatkurrohman. (2014). An analysis of the denotative and connotative meaning of creed's song lyrics. (S.Pd.I) thesis, State Islamic Studies Institute (STAIN), Salatiga. Retrieved from http://e-repository.perpus.iainsalatiga.ac.id/5151/1/AN\%20ANALYSIS\%20ON\%20THE\%20DENOTATIV E\%20AND\%20CONNOTATIVE\%20MEANING\%20OF\%20CR 1.pdf

Fish, J. (2007). Getting equal: The implications of new regulations to prohibit sexual orientation discrimination for health care and social care. Divers Health Soc Care, 4(3), 221-228.

Gedro, J., \& Mizzi, R. C. (2014). Feminist theory and queer theory: Implications for HRD research and practice. Advances in Developing Human Resources, 16(4), 445-456. https://doi.org/10.1177/1523422314543820

GLSEN, CiPHR, \& CCRC (2013). Out online: The experiences of lesbian, gay, bisexual and transgender youth on the Internet. New York: GLSEN. 
Grice, H. P. (1975). Logic and conversation. In P. Cole \& J. L. Morgan (Eds.), syntax and semantics 3: speech acts (pp. 41-58). New York: Academic Press. https://doi.org/10.1163/9789004368811_003

Guardi, J. (2014). Female homosexuality in contemporary Arabic literature. DEP, 25. ISSN 1824-4483.

Hall, W., \& Rodgers, G. (2019). Teachers' attitudes toward homosexuality and the lesbian, gay, bisexual, and queer community in the United States. Social Psychology of Education, 22, 23-41. https://doi.org/10.1007/s11218-018-9463-9

Helie, A. (2012). Risky rights? Gender equality and sexual diversity in Muslims contexts. In A. Helie \& H. Hoodafr (Eds.), Sexuality in Muslims contexts-restrictions and resistance (chapter 11, pp. 294-334). ZED Books. https://doi.org/10.5040/9781350222571.ch-011

Huett, B., Tumlison, C., \& Song, G. (2017). Ideological orientation, LGBT contact, and formation of LGBT policy position. SSRN Electronic Journal. https://doi.org/10.2139/ssrn.2997253

Hynuh, A. (2015). Strategies endorsed by lesbian, gay, bisexual, and transgender (LGBT) to cope with cyberbullying victimization. MA thesis, California State University, Sacramento.

Iroegbu, E. E. (2019). Intellectual bullying and harassment of students by lecturers/supervisors. Unknown Publisher.

Retrieved

from https://www.researchgate.net/publication/335129237_Intellectual_Bullying_and_Harassment_of_Students_ by_LecturersSupervisors.

Jerome, C. (2019). The right to be me, queerly cyberly: Cyber crime and queer individuals in Malaysia. In Exploring the nexus between technologies and human rights: Opportunities and challenges in Southeast Asia. $\quad$ Retrieved from https://www.researchgate.net/publication/338209567_The_Right_to_Be_Me_Queerly_Cyberly_Cyber_Cri me_and_Queer_Individuals_in_Malaysia

Jha, A. K., Raj, A., \& Gangwar, R. (2017). A semiotic analysis of portraying gender in magazine advertisements. Journal of Humanities and Social Science (IOSRJ), 22(5), 01-08.

Keum, B., \& Miller, M. J. (2018). Racism on the internet: Conceptualization and recommendations for research. Psychology of Violence, 8(6). https://doi.org/10.1037/vio0000201

Khodary, Y., Salah, N., \& Mohsen, N. (2020). Middle eastern women between oppression and resistance: Case studies of Iraq, Palestinian, and Kurdish women in Turkey. Journal of International Women's Studies.

Kiss, M. J., Melanie, A., \& Todd, G. (2018). A meta-analytic review of the association between disgust and prejudice toward gay men. Journal of Homosexuality, 67(5), 674-696. https://doi.org/10.1080/00918369.2018.1553349

Kreps, D. (2012). In/visibility of LGBTQ people in Arab spring. Unknown Publisher.

Lanigan, R. L. (1988). Phenomenology of communication: Marleua-Ponty's thematics in communicology and semiology. Pittsburgh, PA: Duquesne University Press.

Lu, W., Chang, Y., Lin, C., \& Yen, C. (2018). Negative Facebook experiences among Taiwanese gay and bisexual men in emerging adulthood: Association with traditional harassment victimization and quality of life. Neuropsychiatric Disease and Treatment, 15, 1163-1170. https://doi.org/10.2147/NDT.S190878

Marbaniang, D. (2014). The Sunni-Sia conflict in Iraq. Comparative Religions, unknown volume/issuance. Retrieved from https://www.researchgate.net/publication/330958990.

Marriott, K. B., \& Meyer, B. (1998). Visual language theory. Springer-Verlag. https://doi.org/10.1007/978-1-4612-1676-6

Mkhize, S., Nunlall, R., \& Gopal, N. (2020). An examination of social media as a platform for cyber-violence against the LGBT+ population. Agenda: Empowering Women for Gender Equity, 34(1), 23-33. https://doi.org/10.1080/10130950.2019.1704485

Nailufar, G. (2014). Analysis the semiotic of racial discrimination in Mandela: A long walk to freedom movie. Sarjana Thesis Pendidkan (S1) thesis, University of Swadaya Gunung Jati Cirebon.

Needham, J. (2013). After the Arab spring: A new opportunity for LGBT human rights advocacy? Duke Journal of Gender, Law, and Policy.

Neo, J. L. C. (2003). Anti-God, anti-Islam, and anti-Quran: Expanding the range of participants and parameters in discourse over women's rights and Islam in Malaysia. Pacific Basin Law Journal, 2, 21-29. 
https://doi.org/10.5070/P8211022165

ORAI. (2016). Arab mass media. A monitoring report looking at sexuality and gender identity in Arabic media from 20142017.2 to 20 Retrieved https://outrightinternational.org/sites/default/files/Eng-ArabicMedia2017-report.pdf

Park, J., Barash, V., Fink, C., \& Cha, M. (2013). Emoticon style: Interpreting differences in Emoticons across cultures. International Conference on Weblogs and social media.

Park, Y., Kim, M., Ko, H., \& Chaffar, S. (2017). Predicting Arab consumers' preference on the Korean contents distribution. Journal of Distribution Science, 15(4), 33-40. https://doi.org/10.15722/jds.15.4.201704.33

Perazzo, B. (n.d.). Policy Brief: On being Shia in Saudi Arabia. A survey looking into the lives of Saudi Arabia's second-class citizens. Institute for Gulf Affairs. Retrieved from https://www.gulfinstitute.org/wp-content/pdfs/shialifeinsaudiarabia.pdf.

Pratt, N. (2007). The Queen Boat Case in Egypt: Sexuality, National Security and State Sovereignty. Review of International Studies, 33(1), 129-144. https://doi.org/10.1017/S0260210507007346

Qibtiyah, A. (2015). Homosexuality Islam and human rights perspectives. Musawa, 14(2). https://doi.org/10.14421/musawa.2015.142.197-210

Rezavn, M., Shekarpour, S., Alshargi, F., Thirunarayan, K., Shalin, V., \& Sheth, A. (2018). Analyzing and learning the language for different types of harassment. PLoS One, 15(3). https://doi.org/10.1371/journal.pone.0227330

Rodriguez, C. (2008). Citizens' media. The International Encyclopedia of Communication. https://doi.org/10.1002/9781405186407.wbiecc029

Saussure, F. de. (1974). In J. Culler (Ed.), W. Baskin (trans.), Course in General Linguistics (1st ed. published in 1915). London: Fontana.

Smith, A. R., \& Martinez, J. M. (1995). Signifying harassment: Communication, ambiguity, and power. Human Studies, 18(1), 63-87. https://doi.org/10.1007/BF01322840

Soni, D., \& Singh, V. (2018). See no evil, hear no evil: Audio-visual-textual cyberbullying detection. CSCW, 2, https://doi.org/10.1145/3274433

Stotzer, R. L. (2012). Comparison of hate crime rates across protected and unprotected groups-An update. The Williams Institute. Retrieved from https://www.researchgate.net/publication/257606451_Comparison_of_Hate_Crime_Rates_Across_Protecte d_and_Unprotected_Groups_-_An_Update

Sujana, N., Setyawati, K., \& Ujanti, N. M. P. (2018). The existence of the lesbian, gay, bisexual, and transgender (LGBT) community in the perspective of a state based on Pancasila. Mimbar-Hakum-Fakultas Hukum Universitas Gadjah Mada, 30(1), 50. https://doi.org/10.22146/jmh.28655

Tag-El-Din, D. (2009). Resisting patriarchy through literature: The feminist writings of Nawal EL Saasawi and Hanan Al-Shaykh. Electronic Theses and Dissertations, 8225.

Takizawa, R., Maughan, B., \& Areseneault, L. (2014). Adult health outcomes of childhood bullying victimization: Evidence from a five-decade longitudinal British birth cohort. American Journal of Psychiatry, 171, 777-784. https://doi.org/10.1176/appi.ajp.2014.13101401

Tomkins, S., Gettor, L., Chen, Y., \& Zhang, Y. (2018). A socio-linguistic model for cyberbullying detection. IEEE/ACM International Conference on Advances in Social Networks Analysis and Mining (ASONAM). https://doi.org/10.1109/ASONAM.2018.8508294

Tracey, P. (2018). Religious beliefs and the queer classroom: Measuring the impact of religious affiliations on LGBTQ-inclusive education practices. Canadian Journal of Educational Administration and Policy, 185, 19-31.

Whitehead, N. (2011). Neither genes nor choice: Same-sex attraction is mostly a unique reaction to environmental factors. Unknown Publisher. Retrieved from https://www.researchgate.net/publication/285329852_Neither_genes_nor_choice_Same-sex_attraction_is_ mostly_a_unique_reaction_to_environmental_factors

Wiederhold, B. K. (2014). Cyberbullying and LGBTQ youth: A deadly combination. Cyberpsychology, Behavior, and Social Networking, 17(9), 569-570. https://doi.org/10.1089/cyber.2014.1521 
Williams, M., \& Robinson, A. (2004). Problems and prospects with policing the lesbian, gay, and bisexual community in Wales. Policing and Society, 14, 213-232. https://doi.org/10.1080/1043946042000241811

Yinggang, W., \& Xuena, C. (2015). A study on cultural connotation of animal word in English and Chinese. International Conference on Education, Management, and Computing Technology (ICEMCT). https://doi.org/10.2991/icemct-15.2015.14

Zamil, R. (2013). Globalization and cultural attitudes of Saudi Arabia's college students: Impact of satellites entertainment. MA thesis, Arizona State University.

Zych, I., Farrington, D. P., LIorent, V. J., \& Ttofi, M. M. (2017). Protecting children against bullying and its consequences. Springer International Publishing. https://doi.org/10.1007/978-3-319-53028-4

\section{Appendix A}

List of harassing expressions found in the data.

Verbal sexually Abusive expressions.

\begin{tabular}{|c|c|c|}
\hline Arabic expression & English translation & Frequency occurrence \\
\hline Mukhanath & Sissy & 116 \\
\hline Shath & Queer & 116 \\
\hline Khawal & Libidinous & 2 \\
\hline Mamhoon & Horny & 17 \\
\hline Louti & A description of someone who has been punished for sodomy & 53 \\
\hline$L a d y^{*}$ & * & 3 \\
\hline Mukhtalif & Different & 2 \\
\hline Okhti & My sister & 1 \\
\hline Bint & Girl & 5 \\
\hline Aher & Slut & 3 \\
\hline Jarrar & Male prostitute & 1 \\
\hline$M n i^{* *}$ & Fucked & 2 \\
\hline Salib & Minus & 2 \\
\hline Fasik & Debauched & 1 \\
\hline Mibsbis & A dialectal term for queer & 14 \\
\hline Bazarnji & A dialectal term for gay & 1 \\
\hline Horma & Woman & 1 \\
\hline Mutahawil & Transgender & 4 \\
\hline Rakasah & Dancer & 1 \\
\hline$K a h^{* *}$ & Prostitute & 2 \\
\hline Mithli & Bisexual & 48 \\
\hline Mankooh & Ridden/ taken over & 1 \\
\hline Gins Talit & Third gender & 2 \\
\hline Gay* & $*$ & 3 \\
\hline Sharm** & Bitch & 1 \\
\hline Nai'm & Softy & 2 \\
\hline Makjoof & A dialectal term for ridden & 1 \\
\hline Markoob & A dialectal term for ridden & 12 \\
\hline Sarboot & Bully & 1 \\
\hline Thokori & Masculine & 1 \\
\hline Suhaki & Lesbian & 1 \\
\hline Khork & Anus & 1 \\
\hline Kurani & A dialectal term for male prostitute & 1 \\
\hline Bagi & Slut & 1 \\
\hline Khikri & Ball-less & 1 \\
\hline Shemale* & * & 1 \\
\hline Pussy* & * & 1 \\
\hline Wirwir & A dialectal term for boyish & 1 \\
\hline Khrinta & People with male and female sexual organs & 1 \\
\hline Dioth & A dialectal term for a man whose wife committed adultery & 2 \\
\hline
\end{tabular}

Note. *Literally borrowed from English. **Highly offensive. 
Verbal politically abusive expressions.

\begin{tabular}{lll}
\hline Arabic expression & English translation & Frequency of occurrence \\
\hline Librali & Liberal & 7 \\
Mulhid & Atheist & 11 \\
Islamphpbic* & $*$ & 2 \\
I'lmani & Secular & 6 \\
Kafir & Faithless & 5 \\
Mutarif & Extremist & 6 \\
Yasari & Belonging to the leftist party & 1 \\
Rafidi & At term used to describe the minor sect in Islam (Shea) & 3 \\
Irhabi & Terrorist & 3 \\
Bothi & Buddhistic & 1 \\
I'r muslism & Non-Muslim & 1 \\
Onsori & Racial & 1 \\
La dini & Non-religious & 4 \\
Zendik & Non-believer & 2 \\
Marik & Renegade & 2 \\
Minafik & Hypocrite & 2 \\
I'dioloi & Having an ideology & 2 \\
Murtad & Apostate & 2 \\
Sheai & Adjectival term for shea & 6 \\
Da'ishi & Being a member of the terrorist group ISIS & 2 \\
Kebob & A member of Kpop & 1 \\
Adou Allah & Anti-God & 1 \\
Muraei & Liar & 1 \\
\hline
\end{tabular}

Note. *Literally borrowed from English.

\section{Verbal intellectually abusive expressions.}

\begin{tabular}{|c|c|c|}
\hline Arabic expression & English translation & Frequency of occurrence \\
\hline Tafih & Radicicolous & 5 \\
\hline Mareed & Sick & 15 \\
\hline Mutakhalif & Barbarian & 2 \\
\hline Mareed nafsi & Psycho & 6 \\
\hline Mukrif & Disgusting & 5 \\
\hline Mujrim & Felon & 22 \\
\hline Batil & Unethical & 4 \\
\hline Mukaziz & Dogmatic & 2 \\
\hline Munhat & Slum & 9 \\
\hline Zibala & Trash & 4 \\
\hline Jaban & Coward & 2 \\
\hline Mukrif & Dirty & 1 \\
\hline Fashil & Loser & 26 \\
\hline Ta'eh & With no goal to achieve & 2 \\
\hline Baheema & Beast & 1 \\
\hline Manbooth & Expelled & 1 \\
\hline Mubtathal & Corny & 3 \\
\hline Hakeer & Bastard & 1 \\
\hline Thid altabe'a & Anti-naturalism & 3 \\
\hline Eme'a & Flunkey & 26 \\
\hline Karithi & Catastrophic & 2 \\
\hline Munharif & Perverted & 1 \\
\hline Mathmom & Deviant & 6 \\
\hline Bigih & Rude & 2 \\
\hline Haiawan & Animal & 2 \\
\hline Kathab & Liar & 13 \\
\hline Jahil & Illiterate & 3 \\
\hline Ghabi & Moron & 9 \\
\hline Q'r tabiee & Un-natural & 4 \\
\hline Fasid & Corrupted & 2 \\
\hline Murjif & Forger & 5 \\
\hline Tanih & Idiot & 1 \\
\hline Wisikh & Ugly & 1 \\
\hline Khabal & Mad & 4 \\
\hline Rwibada & A dialectal term for crazy & 1 \\
\hline Ahmak & Pure Arabic word for idiot & 6 \\
\hline
\end{tabular}




\begin{tabular}{|c|c|c|}
\hline Sathig & Naïve & 3 \\
\hline Mudalis & Fraud & 2 \\
\hline Mirwih & A description of people with low mentality & 1 \\
\hline G'r sawi & Mental-less & 1 \\
\hline Ramil & Mud & 1 \\
\hline Mosokh & Inspidness & 1 \\
\hline Kalb & Dog & 5 \\
\hline Kabeeth & Malignant & 2 \\
\hline Maie & Soft & 7 \\
\hline Wati & Vulgar & 5 \\
\hline Mutanakith & Contradictory & 2 \\
\hline I'fin & Rotten & 3 \\
\hline Mutasalit & Dominator & 3 \\
\hline Saltooh & A dialectal used to describe marginality & 1 \\
\hline Khara & Shit & 1 \\
\hline Waba'a & Epidemic & 2 \\
\hline Ahbal & Asshole & 1 \\
\hline Hamaji & Barbarian & 1 \\
\hline Sakheef & Ridiculous & 4 \\
\hline Najis & Sinful & 2 \\
\hline Natin & Polluted & 5 \\
\hline Abd alshaitan & Emo & 2 \\
\hline Lamamat albshar & Slum of humanity & 1 \\
\hline Wakih & Impolite & 1 \\
\hline Qalb aswad & Black-hearted & 1 \\
\hline Safah & Poacher & 1 \\
\hline Madfoo' & Hit man & 1 \\
\hline Saie' & Street boy & 1 \\
\hline Mukafil & Ninny & 1 \\
\hline Mulawath & Polluted & 1 \\
\hline Safir & Calling for nudity & 2 \\
\hline Sathi & Shallow & 1 \\
\hline Thor & Bull & 2 \\
\hline Jazma & Shoes & 1 \\
\hline Dakheel & Weird & 1 \\
\hline $\mathrm{Ni}$ 'al & A term denoting female heels & 1 \\
\hline Habit & Cursed & 1 \\
\hline Makboot & Inhibited & 1 \\
\hline Nakeera & Indefinite & 1 \\
\hline Sakhat & Torturing & 1 \\
\hline Marfood & Non-acceptable & 1 \\
\hline Mutial & Insane & 2 \\
\hline$Q^{\prime} a l$ & Stray & 1 \\
\hline$A^{\prime} f a$ & Pandemic & 1 \\
\hline Muhan & Profane & 2 \\
\hline G'hareeb & Strange & 2 \\
\hline Dasher & Loiterer & 1 \\
\hline Muta'ri & Naked & 1 \\
\hline Faqeer muhatwa & Contentless & 1 \\
\hline Mutakhabit & Conflicted & 1 \\
\hline Mustafiz & Provocative & 1 \\
\hline Huthlah & Garbage & 1 \\
\hline Garthoma & Germs & 1 \\
\hline Bakteria & Bacteria & 1 \\
\hline Fari'g & Empty & 1 \\
\hline Makhees & A dialect term denoting dirtiness & 1 \\
\hline Bizr & Childish & 1 \\
\hline Sheen & Malformed & 1 \\
\hline Saqit & Futile & 1 \\
\hline Na'eek & Croaking & 1 \\
\hline Ta'oon & Plague & 1 \\
\hline Kabiih & Bad & 1 \\
\hline Tafasukh & Nakedness & 2 \\
\hline Rajei & Deteriorated & 1 \\
\hline Wadi'e & Sinful & 1 \\
\hline Qa'eef & Weak & 2 \\
\hline
\end{tabular}


Verbal racially abusive expressions.

\begin{tabular}{lll}
\hline Arabic expression & English translation & Frequency of occurrence \\
\hline Agnabi & Foreigner & 1 \\
Mujanas & Nationalized (non-indigenous) & 3 \\
Ibn alsh ${ }^{* * *}$ & Son of a bi** & 3 \\
Aqalia & Minorities & 3 \\
Muakhera & Ass & 1 \\
Hajer & Migrate (deport) yourself & 10 \\
Lebnani & Lebanese & 1 \\
La hawia & Identity-less & 2 \\
Iraki & Iraqi & 1 \\
Qatifi & From Al-Qatif (famous among Shea minority) & 1 \\
Ibn alkalb & Puppy (used in a context of an American dog) & 2 \\
Tarbiah wiskha & Sinful environmental upbringings & 3 \\
Souri & Syrian & 2 \\
Eshaboa al-jensyia & Deport (him) & 1 \\
Irani & Irani & 1 \\
Asfahani & Fromm Asfahan, Iran & 1 \\
\hline Note. ${ }^{*}$ Highly offensive. &
\end{tabular}

\section{Verbal appearance-related abusive expressions}

\begin{tabular}{lll}
\hline Arabic expression & English translation & Frequency of occurrence \\
\hline Khism khanzeer & Pork's nose & 1 \\
Filr shafayif & You are putting (lips filler) & 1 \\
Wajhak zai alkhara & Your face is shit & 1 \\
Alda'g & Having a lisp & 2 \\
Sotic na'm & Your voice is soft (girly voice) & 3 \\
Mikiag & You are putting (make-up) & 3 \\
Am't & Hairless & 1 \\
Libs banat & Girly clothes & 3 \\
Amlat & A dialectal term for hairless & 1 \\
Wazn banouti & Girly weight & 1 \\
Foqma & Seal & 1 \\
Krimat bashra & You are putting (facial creams) & 2 \\
Hawajib nawa'm & Girly eyebrows & 1 \\
\hline
\end{tabular}

\section{Appendix B}

\section{Link of humiliating images.}

https://pbs.twimg.com/media/Eh0RqSMWAAEwNfs?format=jpg\&name=900x900

https://pbs.twimg.com/media/Ehd2pXzXcAI-Jsg?format=jpg\&name=medium https://pbs.twimg.com/media/EiU7f01WoAAhDCP?format=jpg\&name=900x900 https://pbs.twimg.com/media/EhfQvp-XgAAHOXg?format=jpg\&name=medium https://pbs.twimg.com/media/EydHFXNWYAAgVV5? format=jpg\&name=medium https:/pbs.twimg.com/media/E09q7LIXMAEUmR7?format=jpg\&name=small https://pbs.twimg.com/media/Es0TL61XMAM_ZzE?format=jpg\&name= $240 \times 240$ https://pbs.twimg.com/media/EzYK1weVgAA1q2P?format=jpg\&name=small https://twitter.com/i/status/1340738855759208449 https://pbs.twimg.com/media/EpwbdIeWwAcPPw0?format=jpg\&name=360x360 https://pbs.twimg.com/media/EqAQVuHW4AEOXta?format=jpg\&name=large https://pbs.twimg.com/media/ExAuS-GWgAI9C7E?format=jpg\&name=900x900 https://pbs.twimg.com/media/ExAwjrbXAAY--cP?format=jpg\&name=medium https://pbs.twimg.com/media/ExFHk8rW8AIazu9? format=jpg\&name=360x360 
https://pbs.twimg.com/media/ElxJ-xnXEAAL8d0?format=jpg\&name=medium https://pbs.twimg.com/media/ElyZjBoWkAAXYKN?format=jpg\&name=small https://pbs.twimg.com/media/Et0ROivXYAMLbHp?format=jpg\&name=large https://pbs.twimg.com/media/Er6E4B-XUAIdF6I?format=jpg\&name=medium https://pbs.twimg.com/media/EywXoKuXMAUTIH7?format=jpg\&name=large https://pbs.twimg.com/media/EWJFiJQWkAEKvPn?format=jpg\&name=900x900 https://pbs.twimg.com/media/EdJGxd2WAAYDOlr?format=jpg\&name=medium

\section{Copyrights}

Copyright for this article is retained by the author, with first publication rights granted to the journal.

This is an open-access article distributed under the terms and conditions of the Creative Commons Attribution license (http://creativecommons.org/licenses/by/4.0/). 